\title{
Effects of Chitosan or Calcium Chloride on External Postharvest Qualities and Shelf-Life of 'Holland' Papaya Fruit
}

\author{
B. Chutichudet ${ }^{1} \&$ Prasit Chutichudet $^{1}$ \\ ${ }^{1}$ Department of Agricultural Technology, Faculty of Technology, Mahasarakham University, Mahasarakham, \\ Thailand \\ Correspondence: B. Chutichudet, Department of Agricultural Technology, Faculty of Technology, \\ Mahasarakham University, Mahasarakham 44150, Thailand. Tel: 66-858-585-450. E-mail: \\ benjawan.c@msu.ac.th
}

Received: August 21, 2014 Accepted: September 10, 2014 Online Published: October 15, 2014

doi:10.5539/jas.v6n11p160 URL: http://dx.doi.org/10.5539/jas.v6n11p160

\begin{abstract}
Papaya (Carica papaya L.) is an important fruit widely cultivated commercially throughout Thailand. Its all year around fruit bearing capability makes papaya a popular fruit with Thai people. Unfortunately, papaya has a very limited shelf-life, as such; the objective of this research was to delay the external postharvest qualities by using chitosan and calcium chloride on the 'Holland' variety of papaya fruit. The experiment was arranged in a Factorial Completely Randomized Design, composed of two factors: coating with chitosan at four concentrations $(1.0,1.5,2.0$ or $2.5 \%)$ or dipping in calcium chloride solution at four levels $(1.0,1.5,2.0$, or $2.5 \%)$, compared with control fruits. After treating, all treatments were stored under ambient temperature $\left(27^{\circ} \mathrm{C}, 80 \%\right.$ R.H. $)$. The results showed that fruit treated with chitosan, irrespective of any concentrations, had the least similar fruit weight loss after six days of storage; however, fruit-treated with $2.5 \%$ chitosan showed the maximum fruit firmness and a delayed red color appearance on the fruit skin. In addition, the best treatment for extending shelf-life proved to be from a treatment of $2.5 \%$ chitosan.
\end{abstract}

Keywords: chitosan, calcium chloride, papaya, skin color, shelf-life

\section{Introduction}

Papaya (Carica papaya L.) is a native tropical fruit from the Americas (Singh, 1990). It is a popular and economically important fruit tree that is typically planted in tropical and subtropical zones (da Silva et al., 2007). Thailand ranks eighth, among nations with producing regions in Asia, South America, North Central America and Africa (Jha et al., 2010). In Thailand, papaya production shows continuous harvest all year-round. Thus, papaya is considered as an important commercial and popular fruit crop cultivated widely in several regions throughout Thailand, ie., Ratchaburi, Nakornpathom, Saraburee, and Nakornratchaseema. Somsri (2014) cited that the total cultivation area in Thailand covers about 17,430 ha. In 2008 the eastern and the southern regions had the largest papaya area of 44 and $16 \%$, respectively with an overall production volume of more than 201,099 t. Papaya is consumed world-wide as a fresh fruit and as a vegetable, especially green papaya salad, which is a famous Thai and Lao food (Boonyaritthongchai \& Kanlayanarat, 2010). In addition, it also used in processed products such as jams, pickles, candies and dried fruit, and desserts (Verheij, 1991; da Silva et al., 2007). Papaya is a good source of vitamin A, vitamin C, calcium, (Arriola, Calzada, Menchu, Role, \& Garcia, 1980; Hayes, 1993), ascorbic acid and potassium (Chan \& Tang, 1979), especially carotene and riboflavin, which acts as an anti-oxidant (De La Cruz Medina, Gutiérrez, \& García, 2003) Thus, papaya consumption is considered as a health benefit, particularly with its excellent medicinal properties, digestion enhancement and relief from constipation (Jayathunge, Prasad, Fernando, \& Palipane, 2011). Its minimally processed state is popular among Thai people (Boonyaritthongchai \& Kanlayanarat, 2010). As it ripens, papaya fruit develops a deep orange-red colored skin while the flesh becomes succulent and aromatic. Phummalee (2013) reported that commercial papaya varieties include Kakdum, Kaknuan, Krung, and Holland. In Thailand, 'Holland' papaya weighs from 800 to 1200 grams per fruit. This variety is famous for its commercial fresh consumption value, attributable to its lack of sap odor, thick flesh sweetness, flesh firmness, and transportation endurance (Krongyut et al., 2011; Phummalee, 2013). Generally, papaya fruit is a highly perishable commodity that is affected by a number of factors leading to postharvest losses (Tasiwal, 2008). After harvest, papaya fruit has a rather limited storage life due to its rapid 
ripening, loss of fruit firmness, peel color change, and diseased appearance (Boonyaritthongchai \& Kanlayanarat, 2010). Postharvest losses in papaya of approximately $40-100 \%$ have been reported in developing countries (Coursey, 1983). Sharma and Alam (1998) reported that postharvest papaya fruit loss is between 40-100 percent of total annual production. Jayathunge et al. (2011) reported that postharvest life of fresh papaya varies from three to six days under tropical climatic conditions, due to enhanced physiological activities such as respiration and other metabolic processes that are associated with fruit deterioration. Chitosan, is a linear polysaccharide consisting of $(1,4)$-linked 2-amino-deoxy- $\beta$-d-glucan, which is extracted from the exoskeleton of crustaceans such as shrimps and crabs. It is also extracted from the cell walls of some fungi (No \& Meyers, 1997). Chitosan has been found to be nontoxic, biodegradable, biofunctional, and biocompatible in addition to having antimicrobial characteristics and versatile chemical and physical properties (Wang, 1992; Darmadji \& Izumimoto, 1994; Jongrittiporn, Kungsuwan, \& Rakshit, 2001; Jayakumar, Prabaharan, Reis, \& Mano, 2005; Jayakumar \& Reis, 2006; Jayakumar, Nwe, Tokura, \& Tamura, 2007; Dutta, Tripathi, Mehrotra, \& Dutta, 2009). Several studies have been done with chitosan as a coating material (Zhang \& Quantick, 1998; El-Ghaouth, Arul, Ponnampalam, \& Boulet, 1991a; El Ghaouth, Arul, \& Asselin, 1991b; Li \& Yu, 2001). Thus, at the present time chitosan is regarded as a promising material for an edible coating in the fruit postharvest field (Olivas \& Barbosa-Cánovas, 2005). For calcium chloride, Lester and Grusak (1999) reported that calcium applications have been known to be effective in terms of membrane functionality and integrity maintenance, which maintains the postharvest life in several fruits. The Nepal Agricultural Research Council reported significantly lower weight loss among stored tomato treated with calcium chloride (Sellars, 2010). However, postharvest research about treating with chitosan or calcium chloride has not been conducted on 'Holland' papaya fruit under ambient temperature. Therefore, this research focused on the effects of chitosan coating or calcium chloride dipping at different concentrations on the external postharvest changes and storage life of 'Holland' papaya fruit stored at room temperature.

\section{Method}

Fresh papaya fruits (variety 'Holland') were harvested at their commercial maturity stage based on peel color (25 $\%$ color break stage) from a commercial orchard in Sarkaew province, in the northeast of Thailand. The fruits were enclosed in styrofoam net sleeves and packed stem-end down in plastic crates. Fruits were carefully transported immediately under ambient condition arriving at the laboratory of the Agricultural Technology Division, Mahasarakham University within six hours after harvest. After they arrived at the laboratory, the fruits were selected again for uniformity in size (average weight of $500 \mathrm{~g}$ ), color, freedom from external damage and free from defects. The experiment was carried out from June to August 2013 at the Division of Agricultural Technology, Faculty of Technology, Mahasarakham University, in the northeast of Thailand. The experiment was conducted in a Factorial in Completely Randomized Design composed of two factors: coating with chitosan or soaking in calcium chloride solution at four levels of concentration at 1.0, 1.5, 2.0, and $2.5 \%$ for $5 \mathrm{~min}$. Each treatment was carried out in four replicates with 10 papaya fruits per replication. After treating, all fruits were allowed to drain and left to dry at room temperature before storage. Non-coated or dipped fruits were used as control. Afterwards, all fruits were stored at ambient temperature of $27{ }^{\circ} \mathrm{C}$ and $80 \% \mathrm{RH}$. The following determinations were made every two days for assessment of fruit weight loss, firmness, peel color, disease incidence, and shelf-life. Weight loss was determined by recording the initial and after storage weight at two day intervals throughout the storage period and expressed as percentage loss of initial weight. Fruit firmness was determined on two opposite sides of each fruit using a penetrometer using a $5 \mathrm{~mm}$ diameter plunger and expressed as $\mathrm{kg} / \mathrm{cm}^{2}$. Peel color determination was made using a Minolta colorimeter model CR-210, Japan in terms of $\mathrm{L}^{*}$ (lightness or brightness ranging from black $=0$ to white $=100$ ); $\mathrm{a}^{*}$ : greenness $(-)$ to redness $(+)$, with and $b^{*}$ values (blueness $(-)$ or yellowness $(+)$ (McGuire, 1992) on the opposite sides of fruits. Decay incidence on the fruit skin was evaluated subjectively according to McDonald et al. (1998), measuring the rotted area on fruit skin and expressing disease severity as a percentage of fruit rot (Sivakumar, Sultanbawa, Ranasingh, $\&$ Wijesundera, 2005). The storage life (days) was considered to terminate when $50 \%$ of fruit senescence. Data was subjected to analysis of variance by SPSS version 6 . The comparisons among means were done by the Least Significant Difference (LSD) at $\mathrm{P} \leq 0.05$. The collected data were statistically analyzed using the SPSS Computer Program, Version 6 (SPSS, 1999).

\section{Results}

After using chitosan or $\mathrm{CaCl}_{2}$ with different concentrations of $1.0,1.5,2.0$, or $2.5 \%$ compared with control, and then stored at ambient temperature the results are presented as follows: 


\subsection{Weight Loss}

Effects of interaction between chemical type and different concentrations, Table 1 showed the increases of fruit weight loss as longer storage time. Papaya fruits soaked in $1.0 \% \mathrm{CaCl}_{2}$ revealed the highest weight loss $(P<0.01)$ during storage at 2,4 , and 6 days after storage (DAS). During the same period, fruits coated with $2.0 \%$ and $2.5 \%$ chitosan had the lowest weight loss percentage. On 8 DAS, the results indicated that interaction of chitosan or $\mathrm{CaCl}_{2}$ application at different concentrations had no effect on the papaya fruit weight loss.

Table 1. Weight loss of papaya fruit after treating with chitosan or $\mathrm{CaCl}_{2}$ at different concentrations

\begin{tabular}{ccccc}
\hline Factor & \multicolumn{5}{c}{ Weight loss (\%) at DAS } \\
\cline { 2 - 5 } & 2 & 4 & 6 & 8 \\
\hline Chemical type & & & & \\
Control & $4.40 \mathrm{a} \pm 0.61$ & $7.84 \mathrm{a} \pm 1.23$ & $11.93 \mathrm{a} \pm 1.92$ & $16.16 \mathrm{a} \pm 0.87$ \\
Chitosan & $3.48 \mathrm{~b} \pm 1.49$ & $6.23 \mathrm{~b} \pm 1.89$ & $8.88 \mathrm{~b} \pm 1.75$ & $12.39 \mathrm{~b} \pm 4.40$ \\
CaCl 2 & $3.72 \mathrm{~b} \pm 1.00$ & $7.20 \mathrm{a} \pm 1.37$ & $11.15 \mathrm{a} \pm 2.11$ & $15.69 \mathrm{a} \pm 3.61$ \\
F-test & $* *$ & $* *$ & $* *$ & $* *$ \\
C.V. $(\%)$ & 23.90 & 23.38 & 19.00 & 26.41 \\
LSD & 0.1877 & 0.2695 & 0.3934 & 1.4194 \\
Conc. $(\%)$ & & & & $11.93 \mathrm{a} \pm 1.92$ \\
0.0 & $4.40 \mathrm{a} \pm 0.61$ & $7.84 \mathrm{a} \pm 1.23$ & $16.16 \pm 0.87$ \\
1.0 & $4.14 \mathrm{a} \pm 0.62$ & $7.47 \mathrm{a} \pm 1.31$ & $11.19 \mathrm{a} \pm 2.33$ & $14.81 \pm 4.12$ \\
1.5 & $4.22 \mathrm{a} \pm 1.88$ & $7.28 \mathrm{a} \pm 2.21$ & $9.97 \mathrm{~b} \pm 2.41$ & $14.61 \pm 4.92$ \\
2.0 & $3.13 \mathrm{~b} \pm 0.68$ & $5.99 \mathrm{~b} \pm 1.20$ & $9.48 \mathrm{~b} \pm 1.80$ & $13.98 \pm 4.26$ \\
2.5 & $3.08 \mathrm{~b} \pm 1.09$ & $6.51 \mathrm{~b} \pm 1.64$ & $10.24 \mathrm{ab} \pm 2.21$ & $14.83 \pm 3.01$ \\
F-test & $* *$ & $* *$ & $*$ & $\mathrm{~ns}$ \\
C.V. $(\%)$ & 23.57 & 23.32 & 21.44 & 28.83 \\
LSD & 0.1673 & 0.2600 & 0.4108 & 1.0913 \\
& & & &
\end{tabular}

Chemical typeX conc.

\begin{tabular}{ccccc} 
Control & $4.40 \mathrm{ab} \pm 0.61$ & $7.84 \mathrm{ab} \pm 1.23$ & $11.93 \mathrm{ab} \pm 1.92$ & $16.16 \pm 0.87$ \\
$1.0 \%$ Chitosan & $3.62 \mathrm{~cd} \pm 0.35$ & $6.12 \mathrm{de} \pm 0.60$ & $8.68 \mathrm{~d} \pm 0.83$ & $11.27 \pm 1.19$ \\
$1.5 \%$ Chitosan & $4.56 \mathrm{a} \pm 2.19$ & $7.35 \mathrm{abc} \pm 2.86$ & $8.44 \mathrm{~d} \pm 1.38$ & $14.38 \pm 7.79$ \\
$2.0 \%$ Chitosan & $2.96 \mathrm{de} \pm 0.86$ & $5.57 \mathrm{e} \pm 1.16$ & $9.18 \mathrm{~d} \pm 1.96$ & $11.50 \pm 1.19$ \\
$2.5 \%$ Chitosan & $2.84 \mathrm{e} \pm 1.21$ & $6.06 \mathrm{de} \pm 1.92$ & $9.12 \mathrm{~d} \pm 2.54$ & $13.09 \pm 5.42$ \\
$1.0 \% \mathrm{CaCl}_{2}$ & $4.30 \mathrm{ab} \pm 0.63$ & $8.22 \mathrm{a} \pm 0.96$ & $12.78 \mathrm{a} \pm 1.65$ & $17.84 \pm 4.06$ \\
$1.5 \% \mathrm{CaCl}_{2}$ & $3.83 \mathrm{bc} \pm 1.44$ & $7.22 \mathrm{abc} \pm 1.58$ & $11.00 \mathrm{bc} \pm 2.44$ & $14.75 \pm 2.56$ \\
$2.0 \% \mathrm{CaCl}_{2}$ & $3.31 \mathrm{cde} \pm 0.43$ & $6.42 \mathrm{cde} \pm 1.12$ & $9.75 \mathrm{~cd} \pm 1.66$ & $15.37 \pm 4.77$ \\
$2.5 \% \mathrm{CaCl}_{2}$ & $3.40 \mathrm{cde} \pm 0.93$ & $6.95 \mathrm{bcd} \pm 1.18$ & $11.07 \mathrm{bc} \pm 1.56$ & $15.18 \pm 2.64$ \\
$\mathrm{~F}-\mathrm{test}$ & $* *$ & $* *$ & $* *$ & $\mathrm{~ns}$ \\
C.V. $(\%)$ & 23.11 & 22.01 & 17.84 & 26.43 \\
LSD & 0.2433 & 0.3640 & 0.5092 & 1.7035 \\
\hline
\end{tabular}

Data were expressed as mean \pm standard deviation (S.D.).

Letters within columns indicate least significant differences (LSD) at $\mathrm{P}^{* *}=0.01, \mathrm{P}^{*}=0.05, \mathrm{NS}=$ non significant. 


\subsection{Fruit Firmness}

The effects of chemical type interaction with various concentrations on fruit firmness, the results showed that papaya fruit firmness began to show highly significant differences after the fourth day. $1.5 \%$ Chitosan treated fruits had the maximal firmness of $4.32 \mathrm{~kg} / \mathrm{cm}^{2}$, while the minimum firmness $\left(1.20 \mathrm{~kg} / \mathrm{cm}^{2}\right)$ was from fruits treated with $2.0 \% \mathrm{CaCl}_{2}$. On 6 DAS, fruit-treated with $2.5 \%$ chitosan showed the maximal firmness of 3.76 $\mathrm{kg} / \mathrm{cm}^{2}$ while most of the other treatments decreased their firmness to be the lower level (Table 2).

Table 2. Fruit firmness of papaya fruit after treating with chitosan or $\mathrm{CaCl}_{2}$ at different concentrations

\begin{tabular}{|c|c|c|c|c|}
\hline \multirow{2}{*}{ Factor } & \multicolumn{4}{|c|}{ Fruit firmness $\left(\mathrm{kg} / \mathrm{cm}^{2}\right)$ at DAS } \\
\hline & 2 & 4 & 6 & 8 \\
\hline \multicolumn{5}{|l|}{ Chemical type } \\
\hline Control & $2.38 b \pm 0.32$ & $3.25 \mathrm{ab} \pm 1.01$ & $0.37 \mathrm{~b} \pm 0.87$ & $0.38 \mathrm{~b} \pm 0.53$ \\
\hline Chitosan & $2.82 \mathrm{ab} \pm 0.84$ & $3.81 \mathrm{a} \pm 0.69$ & $2.15 \mathrm{a} \pm 1.39$ & $2.47 \mathrm{a} \pm 0.99$ \\
\hline $\mathrm{CaCl}_{2}$ & $3.45 \mathrm{a} \pm 1.16$ & $2.45 b \pm 1.43$ & $0.25 b \pm 0.20$ & $0.40 \mathrm{~b} \pm 0.49$ \\
\hline F-test & $*$ & $* *$ & $* *$ & $* *$ \\
\hline C.V. $(\%)$ & 13.93 & 15.66 & 18.60 & 18.15 \\
\hline LSD & 0.2812 & 0.3235 & 0.2686 & 0.34 \\
\hline \multicolumn{5}{|l|}{ Conc. (\%) } \\
\hline 0.0 & $2.38 \pm 0.32$ & $3.25 \pm 1.01$ & $0.37 \mathrm{~b} \pm 0.87$ & $0.38 \pm 0.53$ \\
\hline 1.0 & $2.76 \pm 0.91$ & $3.11 \pm 0.88$ & $0.39 \mathrm{~b} \pm 0.26$ & $1.62 \pm 1.27$ \\
\hline 1.5 & $2.92 \pm 1.11$ & $3.56 \pm 1.31$ & $0.90 \mathrm{ab} \pm 1.14$ & $1.71 \pm 1.46$ \\
\hline 2.0 & $3.14 \pm 0.85$ & $2.54 \pm 1.65$ & $1.63 \mathrm{a} \pm 1.56$ & $1.10 \pm 1.23$ \\
\hline 2.5 & $3.53 \pm 1.19$ & $3.38 \pm 1.24$ & $1.82 \mathrm{a} \pm 1.70$ & $0.38 \pm 0.36$ \\
\hline F-test & ns & ns & $* *$ & ns \\
\hline C.V. (\%) & 13.34 & 14.01 & 11.21 & 19.37 \\
\hline LSD & 0.2811 & 0.3482 & 0.3395 & 0.3794 \\
\hline \multicolumn{5}{|l|}{ Chemical typeX conc. } \\
\hline Control & $2.38 \pm 0.32$ & $3.25 \mathrm{abc} \pm 1.01$ & $0.37 \mathrm{~d} \pm 0.87$ & $0.38 \mathrm{~b} \pm 0.53$ \\
\hline $1.0 \%$ Chitosan & $2.33 \pm 0.60$ & $3.08 b c \pm 0.39$ & $0.68 \mathrm{~d} \pm 0.19$ & $2.44 \mathrm{a} \pm 1.13$ \\
\hline $1.5 \%$ Chitosan & $2.64 \pm 1.16$ & $4.32 \mathrm{a} \pm 0.26$ & $1.64 \mathrm{c} \pm 1.23$ & $3.05 \mathrm{a} \pm 0.50$ \\
\hline 2.0\% Chitosan & $2.73 \pm 0.56$ & $3.88 \mathrm{abc} \pm 0.65$ & $3.07 \mathrm{~b} \pm 0.67$ & $2.41 \mathrm{a} \pm 0.80$ \\
\hline 2.5\% Chitosan & $3.58 \pm 0.47$ & $3.98 \mathrm{ab} \pm 0.77$ & $3.76 \mathrm{a} \pm 0.45$ & $0.90 \mathrm{~b} \pm 0.35$ \\
\hline $1.0 \% \mathrm{CaCl}_{2}$ & $3.58 \pm 1.07$ & $3.00 \mathrm{bc} \pm 1.19$ & $0.12 \mathrm{~d} \pm 0.09$ & $0.80 \mathrm{~b} \pm 0.80$ \\
\hline $1.5 \% \mathrm{CaCl}_{2}$ & $3.20 \pm 1.09$ & $2.80 \mathrm{c} \pm 1.53$ & $0.15 \mathrm{~d} \pm 0.13$ & $0.37 \mathrm{~b} \pm 0.38$ \\
\hline $2.0 \% \mathrm{CaCl}_{2}$ & $3.55 \pm 0.95$ & $1.20 \mathrm{~d} \pm 1.14$ & $0.20 \mathrm{~d} \pm 0.10$ & $0.22 \mathrm{~b} \pm 0.16$ \\
\hline $2.5 \% \mathrm{CaCl}_{2}$ & $3.47 \pm 1.70$ & $2.78 \mathrm{c} \pm 1.38$ & $0.52 \mathrm{~d} \pm 0.18$ & $0.20 \mathrm{~b} \pm 0.12$ \\
\hline F-test & $\mathrm{ns}$ & $* *$ & $* *$ & $* *$ \\
\hline C.V. (\%) & 13.92 & 13.33 & 17.69 & 19.87 \\
\hline LSD & 0.3975 & 0.4148 & 0.2133 & 0.2997 \\
\hline
\end{tabular}

Data were expressed as mean \pm standard deviation (S.D.).

Letters within columns indicate least significant differences (LSD) at $\mathrm{P}^{* *}=0.01, \mathrm{P}^{*}=0.05, \mathrm{NS}=$ non significant. 


\subsection{Peel Color}

With respect to peel color, the average of $\mathrm{L}, \mathrm{a}^{*}$ and $\mathrm{b}^{*}$ values were obtained by measuring peel color during storage. The results from Table 5 showed that different chemical types and concentrations had significant effects on $\mathrm{L}^{*}$ value. Highly significant color differences in terms of $\mathrm{L}^{*}$ were found after 2 DAS through 6 DAS. On 2 and 4 DAS, control fruits showed the maximal $\mathrm{L}^{*}$ (Lightness) value of 53.81 and 58.32, respectively, while fruit treated with $2.5 \%$ chitosan had the lowest $\mathrm{L}^{*}$ on 6 and 8 DAS (Table 3 ). For a* value, control fruits showed the highest a* value (Redness) which was highly significantly different from the other treatments on 2, 4, and 6 DAS The chitosan application at concentrations of 1.5, 2.0 and $2.5 \%$ revealed the similar trend of lower a* value during storage. Meanwhile, fruits treated with all concentrations of $\mathrm{CaCl}_{2}$ showed the similar value of a* compared with control fruit on 8 DAS (Table 4). Finally, for changes of peel color in terms of $b^{*}$ value, the results showed that the control fruits had the maximal $b^{*}$ value (Yellowness) of 44.14 and 50.53 measured on 2 and 4 DAS, respectively. At longer storage of 6 DAS, the results revealed that fruit-treated with $2.5 \%$ chitosan showed the lowest $b^{*}$ value of 34.27 (Table 5).

Table 3. $\mathrm{L}^{*}$ value of papaya fruit after treating with chitosan or $\mathrm{CaCl}_{2}$ at different concentrations

\begin{tabular}{|c|c|c|c|c|}
\hline \multirow{2}{*}{ Factor } & \multicolumn{4}{|c|}{$\mathrm{L}^{*}$ value at DAS } \\
\hline & 2 & 4 & 6 & 8 \\
\hline \multicolumn{5}{|l|}{ Chemical type } \\
\hline Control & $53.81 \mathrm{a} \pm 8.56$ & $58.32 \mathrm{a} \pm 5.49$ & $55.42 \mathrm{a} \pm 3.51$ & $47.05 \pm 4.82$ \\
\hline Chitosan & $47.18 \mathrm{c} \pm 7.79$ & $49.16 \mathrm{c} \pm 8.29$ & $51.69 \mathrm{~b} \pm 10.81$ & $54.83 \pm 9.75$ \\
\hline $\mathrm{CaCl}_{2}$ & $50.99 \mathrm{~b} \pm 8.30$ & $55.16 b \pm 7.23$ & $54.94 \mathrm{ab} \pm 7.30$ & $54.45 \pm 7.94$ \\
\hline F-test & $* *$ & $* *$ & $*$ & ns \\
\hline C.V. $(\%)$ & 16.35 & 14.28 & 16.23 & 15.74 \\
\hline LSD & 0.8849 & 0.8936 & 1.2329 & 2.2204 \\
\hline \multicolumn{5}{|l|}{ Conc. $(\%)$} \\
\hline 0.0 & $53.81 \mathrm{a} \pm 8.56$ & $58.32 \pm 5.49$ & $55.42 \mathrm{a} \pm 3.51$ & $47.05 \pm 4.82$ \\
\hline 1.0 & $52.12 \mathrm{a} \pm 7.75$ & $52.88 \pm 8.69$ & $56.38 \mathrm{a} \pm 6.23$ & $57.12 \pm 8.45$ \\
\hline 1.5 & $49.88 \mathrm{ab} \pm 9.42$ & $52.74 \pm 8.20$ & $52.48 b \mathrm{~b} \pm 8.88$ & $52.54 \pm 8.10$ \\
\hline 2.0 & $47.93 b c \pm 8.05$ & $52.01 \pm 8.49$ & $54.27 \mathrm{ab} \pm 8.00$ & $53.00 \pm 9.10$ \\
\hline 2.5 & $47.25 \mathrm{c} \pm 7.69$ & $54.93 \pm 6.58$ & $49.79 c \pm 11.46$ & $53.47 \pm 8.41$ \\
\hline F-test & $* *$ & ns & $*$ & ns \\
\hline C.V. $(\%)$ & 16.55 & 15.63 & 15.91 & 15.68 \\
\hline LSD & 0.8576 & 0.9954 & 1.1150 & 1.5513 \\
\hline \multicolumn{5}{|l|}{ Chemical typeX conc. } \\
\hline Control & $53.81 \mathrm{a} \pm 8.56$ & $58.32 \mathrm{a} \pm 5.49$ & $55.42 b c \pm 3.51$ & $47.05 \mathrm{de} \pm 4.82$ \\
\hline $1.0 \%$ Chitosan & $50.03 \mathrm{bcd} \pm 7.21$ & $51.85 \mathrm{~cd} \pm 8.85$ & $59.83 \mathrm{a} \pm 7.31$ & $64.12 \mathrm{a} \pm 5.58$ \\
\hline $1.5 \%$ Chitosan & $47.29 \mathrm{de} \pm 9.22$ & $49.70 \mathrm{de} \pm 8.41$ & $52.08 \mathrm{~cd} \pm 8.84$ & $52.28 \mathrm{bcd} \pm 6.08$ \\
\hline 2.0\% Chitosan & $44.70 \mathrm{e} \pm 6.62$ & $47.35 \mathrm{ef} \pm 7.67$ & $51.11 \mathrm{~d} \pm 8.40$ & $47.57 \mathrm{cde} \pm 9.00$ \\
\hline 2.5\% Chitosan & $46.71 \mathrm{de} \pm 7.18$ & $45.76 \mathrm{f} \pm 6.33$ & $42.40 \mathrm{e} \pm 11.77$ & $44.75 \mathrm{e} \pm 1.72$ \\
\hline $1.0 \% \mathrm{CaCl}_{2}$ & $52.53 \mathrm{ab} \pm 7.10$ & $55.27 \mathrm{abc} \pm 7.66$ & $54.16 \mathrm{bcd} \pm 5.77$ & $53.90 \mathrm{bc} \pm 5.77$ \\
\hline $1.5 \% \mathrm{CaCl}_{2}$ & $52.47 \mathrm{ab} \pm 9.00$ & $55.18 \mathrm{abc} \pm 7.62$ & $52.81 \mathrm{~cd} \pm 9.05$ & $52.72 \mathrm{bcd} \pm 9.41$ \\
\hline $2.0 \% \mathrm{CaCl}_{2}$ & $51.17 \mathrm{abc} \pm 8.13$ & $56.01 \mathrm{ab} \pm 7.13$ & $57.23 \mathrm{ab} \pm 6.44$ & $56.02 \mathrm{~b} \pm 7.86$ \\
\hline $2.5 \% \mathrm{CaCl}_{2}$ & $47.78 \mathrm{cde} \pm 8.22$ & $54.19 b c \pm 6.67$ & $55.60 \mathrm{bc} \pm 7.14$ & $55.21 \mathrm{~b} \pm 8.12$ \\
\hline F-test & $* *$ & $* *$ & $* *$ & $* *$ \\
\hline C.V. $(\%)$ & 16.06 & 14.11 & 14.53 & 13.64 \\
\hline LSD & 1.2295 & 1.2728 & 1.5123 & 2.2982 \\
\hline
\end{tabular}

Data were expressed as mean \pm standard deviation (S.D.).

Letters within columns indicate least significant differences (LSD) at $\mathrm{P}^{* *}=0.01, \mathrm{P}^{*}=0.05, \mathrm{NS}=$ non significant. 
Table 4. $\mathrm{a}^{*}$ value of papaya fruit after treating with chitosan or $\mathrm{CaCl}_{2}$ at different concentrations

\begin{tabular}{|c|c|c|c|c|}
\hline \multirow{2}{*}{ Factor } & \multicolumn{4}{|c|}{$a^{*}$ value at DAS } \\
\hline & 2 & 4 & 6 & 8 \\
\hline \multicolumn{5}{|l|}{ Chemical type } \\
\hline Control & $6.11 \mathrm{a} \pm 4.45$ & $17.46 \mathrm{a} \pm 8.77$ & $22.40 \mathrm{a} \pm 4.92$ & $17.31 \mathrm{a} \pm 5.88$ \\
\hline Chitosan & $-4.46 c \pm 6.93$ & $-1.05 \mathrm{c} \pm 10.07$ & $2.03 \mathrm{c} \pm 10.75$ & $3.53 b \pm 9.83$ \\
\hline $\mathrm{CaCl}_{2}$ & $0.80 \mathrm{~b} \pm 4.06$ & $12.43 b \pm 10.63$ & $18.30 \mathrm{~b} \pm 7.53$ & $18.94 \mathrm{a} \pm 8.04$ \\
\hline F-test & $* *$ & $* *$ & $*$ & $* *$ \\
\hline C.V. $(\%)$ & 17.93 & 13.98 & 13.75 & 16.57 \\
\hline LSD & 0.9668 & 1.2066 & 1.2509 & 2.2488 \\
\hline \multicolumn{5}{|l|}{ Conc. $(\%)$} \\
\hline 0.0 & $6.11 \mathrm{a} \pm 7.45$ & $17.46 \pm 8.77$ & $22.40 \mathrm{a} \pm 4.92$ & $17.31 \pm 5.88$ \\
\hline 1.0 & $2.55 \mathrm{a} \pm 10.78$ & $6.72 \pm 8.90$ & $17.18 \mathrm{a} \pm 8.86$ & $16.38 \pm 8.11$ \\
\hline 1.5 & $-0.64 b \pm 9.21$ & $7.69 \pm 7.09$ & $10.76 \mathrm{~b} \pm 10.97$ & $10.88 \pm 8.96$ \\
\hline 2.0 & $-3.73 c \pm 8.27$ & $5.77 \pm 10.56$ & $11.14 \mathrm{~b} \pm 6.96$ & $12.95 \pm 7.63$ \\
\hline 2.5 & $-3.74 c \pm 6.94$ & $9.68 \pm 10.09$ & $5.95 \mathrm{c} \pm 7.15$ & $12.73 \pm 9.08$ \\
\hline F-test & $* *$ & ns & $* *$ & ns \\
\hline C.V. $(\%)$ & 12.01 & 14.04 & 16.46 & 18.82 \\
\hline LSD & 0.9551 & 1.5102 & 1.5095 & 2.0477 \\
\hline \multicolumn{5}{|l|}{ Chemical typeX conc. } \\
\hline Control & $6.11 \mathrm{a} \pm 10.45$ & $17.46 \mathrm{a} \pm 8.77$ & $22.40 \mathrm{a} \pm 4.92$ & $17.31 \mathrm{ab} \pm 5.88$ \\
\hline $1.0 \%$ Chitosan & $-1.15 \mathrm{~cd} \pm 9.96$ & $3.04 \mathrm{~d} \pm 1.91$ & $11.85 \mathrm{c} \pm 9.94$ & $13.40 \mathrm{~b} \pm 7.12$ \\
\hline $1.5 \%$ Chitosan & $-4.92 \mathrm{e} f \pm 5.87$ & $-1.42 \mathrm{de} \pm 1.43$ & $0.16 \mathrm{~d} \pm 9.12$ & $-1.04 c \pm 7.36$ \\
\hline $2.0 \%$ Chitosan & $-7.59 \mathrm{f} \pm 3.51$ & $-2.71 \mathrm{e} \pm 1.63$ & $1.45 \mathrm{~d} \pm 9.17$ & $-1.87 \mathrm{c} \pm 3.84$ \\
\hline $2.5 \%$ Chitosan & $-4.19 \mathrm{def} \pm 5.31$ & $-5.47 \mathrm{e} \pm 0.94$ & $-6.83 e \pm 4.72$ & $-6.43 c \pm 2.68$ \\
\hline $1.0 \% \mathrm{CaCl}_{2}$ & $2.70 \mathrm{ab} \pm 10.89$ & $13.91 \mathrm{ab} \pm 1.71$ & $17.62 \mathrm{~b} \pm 7.83$ & $19.02 \mathrm{ab} \pm 9.09$ \\
\hline $1.5 \% \mathrm{CaCl}_{2}$ & $3.65 \mathrm{ab} \pm 9.98$ & $15.10 \mathrm{ab} \pm 1.74$ & $19.23 \mathrm{ab} \pm 8.63$ & $19.23 \mathrm{ab} \pm 8.76$ \\
\hline $2.0 \% \mathrm{CaCl}_{2}$ & $0.13 b c \pm 9.78$ & $12.43 b c \pm 1.83$ & $20.19 \mathrm{ab} \pm 5.25$ & $21.17 \mathrm{a} \pm 6.71$ \\
\hline $2.5 \% \mathrm{CaCl}_{2}$ & $-3.29 \mathrm{cde} \pm 8.30$ & $8.27 \mathrm{c} \pm 1.66$ & $16.00 \mathrm{bc} \pm 7.69$ & $16.56 \mathrm{ab} \pm 7.41$ \\
\hline F-test & $* *$ & $* *$ & $* *$ & $* *$ \\
\hline C.V. $(\%)$ & 25.52 & 12.46 & 16.35 & 15.29 \\
\hline LSD & 1.3282 & 1.6954 & 1.5053 & 2.3003 \\
\hline
\end{tabular}

Data were expressed as mean \pm standard deviation (S.D.).

Letters within columns indicate least significant differences (LSD) at $\mathrm{P}^{* *}=0.01, \mathrm{P}^{*}=0.05, \mathrm{NS}=$ non significant. 
Table 5. $\mathrm{b}^{*}$ value of papaya fruit after treating with chitosan or $\mathrm{CaCl}_{2}$ at different concentrations

\begin{tabular}{|c|c|c|c|c|}
\hline \multirow{2}{*}{ Factor } & \multicolumn{4}{|c|}{$\mathrm{b}^{*}$ value at DAS } \\
\hline & 2 & 4 & 6 & 8 \\
\hline \multicolumn{5}{|l|}{ Chemical type } \\
\hline Control & $44.14 \mathrm{a} \pm 9.90$ & $50.53 a \pm 5.74$ & $47.30 \pm 7.32$ & $28.90 \mathrm{~b} \pm 7.09$ \\
\hline Chitosan & $37.75 b \pm 9.45$ & $40.49 c \pm 7.09$ & $44.89 \pm 8.35$ & $47.60 \mathrm{a} \pm 6.70$ \\
\hline $\mathrm{CaCl}_{2}$ & $38.91 \mathrm{~b} \pm 8.23$ & $46.75 b \pm 9.69$ & $46.25 \pm 10.63$ & $44.74 \mathrm{a} \pm 8.56$ \\
\hline F-test & $* *$ & $* *$ & ns & $* *$ \\
\hline C.V. $(\%)$ & 26.51 & 22.47 & 24.30 & 27.65 \\
\hline LSD & 1.1272 & 1.1816 & 1.5756 & 3.2342 \\
\hline \multicolumn{5}{|l|}{ Conc. (\%) } \\
\hline 0.0 & $44.14 \mathrm{a} \pm 9.90$ & $50.53 \pm 5.74$ & $47.30 \mathrm{a} \pm 7.32$ & $28.90 \pm 7.09$ \\
\hline 1.0 & $41.27 \mathrm{a} \pm 10.60$ & $44.25 \pm 10.68$ & $48.47 \mathrm{a} \pm 10.87$ & $48.49 \pm 8.93$ \\
\hline 1.5 & $40.21 \mathrm{ab} \pm 10.94$ & $45.06 \pm 8.47$ & $45.91 \mathrm{a} \pm 9.03$ & $42.62 \pm 10.91$ \\
\hline 2.0 & $37.40 \mathrm{bc} \pm 9.13$ & $43.70 \pm 10.03$ & $46.14 \mathrm{a} \pm 10.46$ & $44.66 \pm 9.57$ \\
\hline 2.5 & $35.87 \mathrm{c} \pm 10.21$ & $45.17 \pm 9.81$ & $41.00 \mathrm{~b} \pm 9.06$ & $43.16 \pm 10.74$ \\
\hline F-test & $* *$ & ns & $*$ & ns \\
\hline C.V. $(\%)$ & 26.40 & 23.95 & 15.91 & 28.58 \\
\hline LSD & 1.0748 & 1.2815 & 1.1150 & 2.3450 \\
\hline \multicolumn{5}{|l|}{ Chemical typeX conc. } \\
\hline Control & $44.14 \mathrm{a} \pm 9.90$ & $50.53 a \pm 5.74$ & $47.30 \mathrm{~b} \pm 7.32$ & $28.90 \mathrm{e} \pm 7.09$ \\
\hline $1.0 \%$ Chitosan & $41.31 \mathrm{ab} \pm 10.58$ & $44.11 \mathrm{cde} \pm 7.86$ & $54.11 \mathrm{a} \pm 9.62$ & $59.30 \mathrm{a} \pm 7.63$ \\
\hline $1.5 \%$ Chitosan & $37.28 b c \pm 10.48$ & $40.78 \mathrm{ef} \pm 8.77$ & $46.29 \mathrm{~b} \pm 10.70$ & $45.45 \mathrm{bc} \pm 8.97$ \\
\hline $2.0 \%$ Chitosan & $33.75 \mathrm{c} \pm 6.13$ & $38.93 \mathrm{fg} \pm 10.46$ & $43.49 \mathrm{~b} \pm 8.14$ & $37.61 \mathrm{cde} \pm 9.62$ \\
\hline $2.5 \%$ Chitosan & $38.64 b \pm 8.61$ & $35.59 \mathrm{~g} \pm 6.66$ & $34.27 \mathrm{c} \pm 8.14$ & $33.27 \mathrm{de} \pm 6.04$ \\
\hline $\mathrm{CaCl}_{2} 1.0 \%$ & $38.35 b \pm 10.74$ & $45.71 \mathrm{bcd} \pm 10.57$ & $44.52 b \pm 9.39$ & $45.04 b c \pm 10.63$ \\
\hline $\mathrm{CaCl}_{2} 1.5 \%$ & $43.14 \mathrm{a} \pm 10.72$ & $49.53 \mathrm{ab} \pm 9.04$ & $45.60 \mathrm{~b} \pm 10.46$ & $40.64 \mathrm{bcd} \pm 9.90$ \\
\hline $\mathrm{CaCl}_{2} 2.0 \%$ & $41.04 \mathrm{ab} \pm 10.20$ & $48.38 \mathrm{abc} \pm 9.10$ & $48.60 \mathrm{ab} \pm 8.05$ & $48.57 \mathrm{~b} \pm 8.08$ \\
\hline $\mathrm{CaCl}_{2} 2.5 \%$ & $33.10 \mathrm{c} \pm 9.02$ & $43.39 \mathrm{def} \pm 9.14$ & $46.29 \mathrm{~b} \pm 10.22$ & $45.14 b c \pm 9.88$ \\
\hline F-test & $* *$ & $* *$ & $* *$ & $* *$ \\
\hline C.V. $(\%)$ & 15.49 & 21.95 & 22.41 & 24.56 \\
\hline LSD & 1.5327 & 1.6632 & 1.9908 & 3.432 \\
\hline
\end{tabular}

Data were expressed as mean \pm standard deviation (S.D.).

Letters within columns indicate least significant differences (LSD) at $\mathrm{P}^{* *}=0.01, \mathrm{P}^{*}=0.05, \mathrm{NS}=$ non significant.

\subsection{Disease Incidence}

The degree of disease incidence on skin fruit rapidly increased during storage. Throughout the storage period, no obviously fruit rot percentage was found. The results presented in Figure 1. indicated that different chemical types varied in five concentrations resulted in the similar disease appearance though 6 DAS. 




Figure 1. Decay percentage of papaya fruit after treating with chitosan or $\mathrm{CaCl}_{2}$ at different concentrations on 6 DAS

Data were expressed as mean \pm standard deviation (S.D.).

\subsection{Shelf-Life}

The results from Figure 2. showed that different chemical type at various concentrations had highly significant effect on shelf-life. Papaya fruit-treated with $2.5 \%$ chitosan had a markedly effect on the maximal storage life of 11.00 days, while the control fruits had the minimal postharvest life only of 7.00 days.

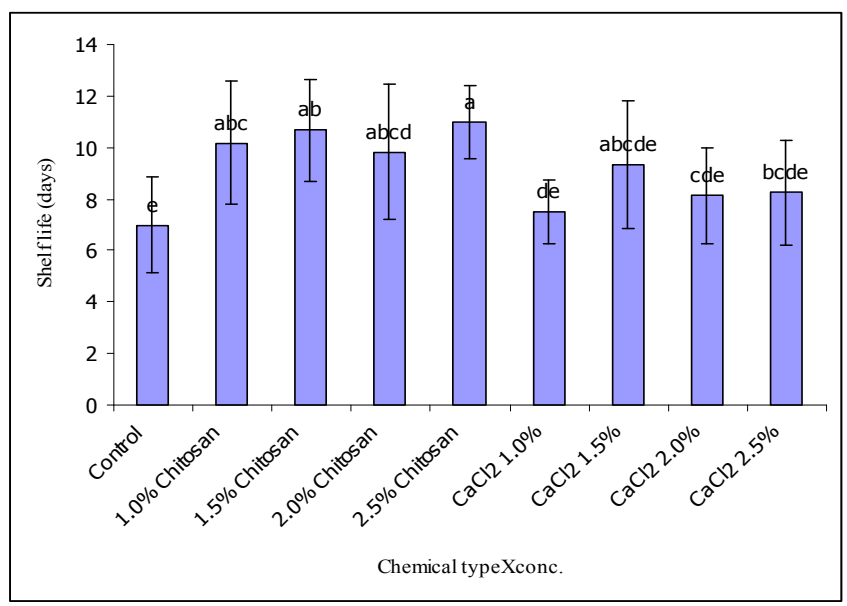

Figure 2. Shelf-life of papaya fruit after treating with chitosan or $\mathrm{CaCl}_{2}$ at different concentrations

Data were expressed as mean \pm standard deviation (S.D.).

\section{Discussion}

The research tested the effects of chitosan or $\mathrm{CaCl}_{2}$ treatments at different concentrations $(0,1.0,1.5,2.0$, and $2.5 \%$ ) on the postharvest life and some external characteristics of 'Holland' papaya fruit. Fruit weight loss of the papaya fruit during storage is shown in Table 1 . The results revealed that during storage, the significant differences of papaya weight loss steadily declined throughout storage life and were variable among the treatments. Postharvest chitosan coating at conc. of $2.0 \%$ and $2.5 \%$ significantly decreased weight loss and showed highly significant difference between other treatments $(P<0.01)$. It is evident from Table 1 that treating with $2.0 \%$ and $2.5 \%$ chitosan led to a marked reduction in weight loss compared to other treatments. Therefore, $2.0 \%$ and $2.5 \%$ chitosan treatments were the most effective in delaying the increase of papaya fruit weight loss, while papaya fruits treated with $1.0 \% \mathrm{CaCl}_{2}$ showed the significantly highest weight loss after 2,4 and 6 days of storage (DAS) compared with the other treatments. Generally, papaya fruit is composed of high water content 
and susceptible to postharvest shriveling (Postharvest Handling Technical Bulletin, 2003). Loss of weight in fresh fruit is mainly due to the loss of water caused by transpiration and respiration processes (Proulx, Cecilia, Nunes, Emond, \& Brecht, 2005). Li, Dunn, Grandmaison, and Goosen (1992) reported that chitosan has a film-forming ability, which serves as a moisture barrier to avoid the dehydration processes during fruit storage (El Ghaouth, Arul, \& Ponnampalam, 1991c; Wong, Gastineau, Gregorski, Tillin, \& Pavlath, 1992; Butler, Vregano, Testin, Bunn, \& Wiles, 1996). Similar weight loss was reported by Maftoonazad and Ramaswamy (2005) who cited that slower rates of moisture loss in coated fruits can be attributed to the moisture barrier properties for regulating the transpiration process between fruit and environment (Salunkhe, Boun, \& Reddy, 1991; Reddy, Belkacemi, Corcuff, Castaigne, \& Arul, 2000). In addition, strawberry-coated with $1.5 \%$ chitosan is effective in delaying moisture loss and fruit shriveling (Hernández-Muñoz, Almenar, Ocio, \& Gavara, 2006). These beneficial results of chitosan application are also in line with Sivakumar et al., (2005); Zhang and Quantick (1997); Dong, Cheng, Tan, Zheng, and Jiang (2004); Huaqiang, Cheng, Tan, Zheng, and Jiang (2004). Another reason for reducing weight losses of papaya fruit treated with $2.0 \%$ and $2.5 \%$ chitosan during storage can be explained by the modified atmosphere and selectively permeated of $\mathrm{C}_{2} \mathrm{H}_{4}, \mathrm{CO}_{2}$ and $\mathrm{O}_{2}$ inside fruit created from chitosan coating. These functions of chitosan may be related to decrease fruit respiration, resulting in less weight loss (Gonza'lez-Aguilar, Buta, \& Wang, 2003; Sivakumar et al. 2005; Xianghong, Li, Liu, \& Tian, 2008). Dong et al. (2004) also found that the properties of film formed by chitosan, including moisture barrier and selective permeability of gas, are related to its concentration (Wiles, Vergano, Barron, Bunn, \& Testin, 2000; Park, Marsh, \& Rhim, 2002). Thus, the results indicated that chitosan at conc. of $2.0 \%$ and $2.5 \%$ gave better results in terms of less weight losses, probably because of the higher viscosity of chitosan solution (Caro \& Joas, 2005). Nevertheless, moisture barrier properties of chitosan-coated fruit have not been assessed yet, and there is no published studies on the effect of chitosan coatings on the weight loss of 'Holland' papaya. The opposite findings in a previous report by Kakaew, Nimitkeatkai, Srilaong, and Kanlayanarat (2007), who reported that an application of $0.5 \%$ calcium chloride to shredded green papaya 'Kaek Dum' resulted in a reduction of weight loss during storage. Mahajan and Dhatt (2004) reported that $\mathrm{CaCl}_{2}$ treated pear fruit could reduce the rate of respiration and transpiration, leading to reduce fruit weight loss during 75 days of storage. These opposing results were also confirmed by Rajkumar, Karuppaiah, and Kandasamy (2005) who indicated that post-harvest treatment of papaya fruits in $\mathrm{CaCl}_{2} 2 \%$ for 5 min recorded significantly the lowest level of fruit weight loss.

In case of fruit firmness, the effect of chitosan or $\mathrm{CaCl}_{2}$ on papaya fruit firmness during storage is shown in Table 2. The results showed that fruit firmness of papaya was reduced with increments of storage period. Fruit firmness was highly significant in fruit-coated with chitosan compared with $\mathrm{CaCl}_{2}$ and untreated control. Fruit firmness of papaya showed that treatment with all concentration of chitosan remarkably delayed the loss of fruit firmness more than the control and $\mathrm{CaCl}_{2}$-treated fruits on 4 and $6 \mathrm{DAS}$. Fruit-treated with $1.5 \%$ chitosan retained the maximal firmness of $4.32 \mathrm{~kg} / \mathrm{cm}^{2}$ on 4 DAS, while $2.5 \%$ chitosan treated fruit had a positive effect on maintaining the maximal fruit firmness $\left(3.76 \mathrm{~kg} / \mathrm{cm}^{2}\right)$ on 6 DAS. Thus, the results indicated that chitosan application is more effective in retaining 'Holland' papaya fruit firmness than $\mathrm{CaCl}_{2}$. Papaya is considered as a climacteric fruit and exhibits a characteristic rise in flesh softening (da Silva et al., 2007). Paull and Chen (1983) cited that postharvest papaya fruit ripening involves softening due to the activity of cell wall-degrading enzymes. These results indicated that a positive effect of chitosan on fruit firmness. These effects can be attributed to formation of a chitosan film on fruit surface which act as a barrier for $\mathrm{O}_{2}$ uptake thereby slowing the metabolic activity, and consequently the ripening process (Reddy et al., 2000). Several researches indicate that fruit-treated with chitosan, including, strawberries, raspberries, tomatoes, peaches, and papayas could delay their firmness during the storage period (El Ghaouth et al., 1991b, El-Ghaouth, Ponnampalam, Castaigne, \& Arul, 1992a; EI Ghaouth, Arul, Grenier, \& Asselin, 1992b; Li \&Yu, 2000; Bautista-Baños, Hernández-López, Bosquez-Molina, \& Wilson, 2003). A similar finding in a previous report by Hernández-Muñoz et al. (2006) who found that a modified atmosphere condition owing to chitosan coating was an effective method for slowing down fruit respiration and maintaining fruit firmness. Similar results are obtained with Martínez-Castellanos, Shirai, Pelayo-Zaldívar, Pérez-Flores, and Sepúlveda-Sánchez (2009), who cited that chitosan treatment showed higher fruit firmness, due to the effect of chitosan coating on biochemical activities inside fruits. These results are in accordance to El-Ghaouth, Smilanick, and Wilson (2000), who found that chitosan coatings significantly affected the retention of firmness by the modification of the endogenous level of $\mathrm{CO}_{2}$ and reduction of the ethylene. Reddy et al. (2000) also cited that the maintenance of fruit texture was dependent on chitosan concentration, storage time and temperature. They reported that fruit texture was firmer with increasing chitosan concentration, and it decreased with storage temperature and time. In addition, loss of fruit texture is also dependent on loss of fruit weight due to transpiration and respiration (Bourne, 1983). However, these results showed that $\mathrm{CaCl}_{2}$ application at different concentrations in this experiment had no significant affect to 'Holland' papaya firmness. In spite of this 
it is well known that calcium plays a major role in maintaining the delay of softening (Poovaiah, 1986), due to calcium stabilizing the cell membrane (Picchioni, Watada, Conway, Whitaker, \& Sams, 1995). These results are not consistent with the previous study that reported calcium dips have been used as firming agents in strawberries (Garcia, Herrera, \& Morilla, 1996), sliced pears and sliced strawberries (Rosen \& Kader, 1989) and zucchini slices (Izumi \& Watada, 1995). Luna-Guzmán, Cantwell, and Barrett (1999) also reported that application of calcium treatments, especially $2.5 \%$ calcium chloride resulted in holding the firmness of melon fruit over 10 days of storage. Our results are not consistent with the previous study reported for peach (Manganaris, Vasilakakis, Diamantidis, \& Mignani, 2007) and papaya (Eryani-Raqeeb, Mahmud, \& Omar, 2009). However, due to the calcium uptake via the fruit surface being very small (Conway, Sams, McGuire, \& Kelman, 1992) a decrease in firmness of various fruit-treated with $\mathrm{CaCl}_{2}$ has also been reported by previous workers. Thus, a negligible amount of $\mathrm{CaCl}_{2}$ can be absorbed and become the structural calcium led to fail to improve fruit firmness (Huang et al., 2008). Furthermore, calcium salts can accelerate the senescing-related processes, depending on calcium concentration (Conway, Sams, \& Kelman, 1994; Saftner, Conway, \& Sams, 1998).

With respect to peel color, the fruit skin colors of 'Holland' papaya fruit were assessed during storage life period with a chromameter using the CIELAB system. Significant effects of chitosan treating $(\mathrm{P}<0.01)$ were presented for fruit skin in terms of $\mathrm{L}^{*}, \mathrm{a}^{*}$ and $\mathrm{b}^{*}$ values in Table 3, Table 4, and Table 5. Skin lightness ( $\left.\mathrm{L}^{*}\right)$ was affected by chitosan treatment during storage. The lower values of lightness were observed from fruit-treated with chitosan, especially $2.5 \%$ chitosan since 2 DAS through 6 DAS. These results imply that papaya fruit-treated with $2.5 \%$ chitosan rendered the skin less bright. This is in harmony with Hernández-Muñoz et al. (2006), who found that strawberry-coated with chitosan darkened slightly after the second day of storage. Chien, Sheu, and Yang (2007) revealed that the $L^{*}$ values of sliced mangoes-treated with $0.5 \%, 1 \%$ and $2 \%$ chitosan underwent changes in lightness during storage. A possible explanation for the effects of chitosan may have resulted from the chitosan film coated on the fruit skin. For a* value (redness) of each treatment showed rapid increase throughout the storage period. As in Table 4, the a* value from fruit-treated with chitosan were more negative than those-treated with $\mathrm{CaCl}_{2}$ and Control fruits. Generally, the a* value is a measure of greenness and is highly correlated with the color changes of the fruit (Goupy et al., 1995). An increase in $a^{*}$ value is an indicative of fruit nearly ripe (Mastrocola \& Lerici, 1991; Monsalve-González, Barbosa-Cánovas, Cavalieri, McEvily, \& Iyengar, 1993).These results indicated that the skin of papaya treated with chitosan will be greener than the others. The results showed that fruit skin color rapidly shifted toward the positive a* value on fruit treated with $\mathrm{CaCl}_{2}$ and control fruits, indicating that these fruits in the above treatments changed to become more red in color, which was the result of fruit ripening. Similar findings were proved by Chávez-Sánchez, Carrillo-López, Vega-García, and Yahia (2013) who observed though 8 DAS of storage life 'Maradol' papaya fruit treated with chitosan turned to decrease in a* value (less red). Similar results were observed in papaya cv 'Solo' by Hundtoft and Akamine (1971). For b* value (yellowness), the results from Table 5 showed that fruit-treated with $2.5 \%$ chitosan had less $b^{*}$ value than those treated with $\mathrm{CaCl}_{2}$ or control fruit. These decreases in $\mathrm{b}^{*}$ value from fruit-treated with $2.5 \%$ chitosan indicated more reduction in yellowness of skin color than the others. A similar result was confirmed by Ducamp-Collin, Ramarson, Lebrun, Self, and Reynes (2008) who reported that the chitosan treatment effectively fixed the fruit coloration during storage. An explanation for delay of fruit color change is that it may be due to chitosan films coatings on the fruit reducing moisture transfer, restricting oxygen uptake, lowering respiration, retarding ethylene production, and potential discoloration (Dutta et al., 2009). In addition, the effect of the film barrier provided by chitosan increased the internal $\mathrm{CO}_{2}$ concentrations, led to delay color development in papaya fruit (da Silva et al., 2007). Thus, the results indicated that chitosan affected to delay the fruit color development, especially a decrease in surface redness (a* value) and yellowness ( $b^{*}$ value) on papaya fruit during storage. Similarly, Shahidi, Kamil, Arachchi, and Jeon (1999) found that due to its ability to form semi-permeable film, chitosan coating can be expected to modify the internal atmosphere as well as decrease the transpiration loss (El Ghaouth et al., 1991a). Another possible explanation was that the chitosan coating functioned as a self control atmosphere and selectively permeated $\mathrm{C}_{2} \mathrm{H}_{4}, \mathrm{CO}_{2}$ and $\mathrm{O}_{2}$ inside and out of the fruit, thus reducing fruit respiration metabolism (Bai, Huang, \& Jiang, 1988; El Ghaouth et al., 1991a; Hagenmaier, 2005). This may be related to delay the ripening of fruits (El Ghaouth et al., 1992a). Pen and Jiang (2003) and Hernández-Muñoz et al. (2006) also cited that treatment with chitosan coating delayed the development of the discoloration in fresh-cut Chinese water chestnut and strawberries, respectively. Thus, the use of film waxing of papaya has been successful in retarding color development (Paull \& Chen, 1989).

In the case of disease incidence, decay severity was recorded according to the rotten area appearing on the papaya fruit during storage. The change of disease appearance values with increasing storage period is given in Table 6 . However, recording fruit rot appearance at two daily intervals of all treatments showed similar manners. Thus, both chitosan and $\mathrm{CaCl}_{2}$ used in this experiment at concentrations of $1.0,1.5,2.0$, and $2.5 \%$ were not effective in 
controlling fruit decay during storage under ambient temperature. Thus, the results may indicate that there is no any advantage of chitosan or $\mathrm{CaCl}_{2}$ on the disease appearance on papaya fruit during storage. Asgar, Muhammad, Sijam, and Siddiqui (2010) found that after harvest, papaya fruit is susceptible to several diseases. At longer storage times, the occurrence of fruit rot proceeded. These results did not agree with those published by Ali (2006) who reported that chitosan coatings of $1.0 \%, 1.5 \%$ and $2.0 \%$ were not only effective in controlling papaya fruit decay but also delayed the onset of disease symptoms and slowed down the disease progress. While Qiuping and Wenshui (2007) and Dutta et al. (2009) cited that chitosan coating can form a protective barrier on the surface of fresh fruit, and bring about to decrease microbial growth that causes fruit rotting. Previous studies indicated that chitosan coating had the potential to control decay of many fruits, such as strawberry, peach, table grape, apple and mango (Chien et al., 2007; Dong et al., 2004; Maria, Tapiab, \& Bellosoa, 2008; Romanazzi, Nigro, Ippolito, Di Venere, \& Salerno, 2002). However, Devlieghere, Vermeulen, and Debevere (2004) found that the antimicrobial activity of chitosan will depend on several factors such as the kind of chitosan, storage temperature, and food components. Vargas, Albors, Chiralt, and González-Martínez (2006) also found that chitosan has proved to be effective to control decay of cold-stored strawberries (El Gaouth et al., 1991a; Zhang \& Quantick, 1998; Han, Zhao, Leonard, \& Traber, 2004). While the opposite findings were reported by Klein and Lurie (1992) who cited that calcium treatments can reduce the severity of pathogen attack in horticultural crops (Conway et al., 1992; Ferguson, 1984). Rajkumar et al. (2005) found that post-harvest treatment of papaya fruits in $\mathrm{CaCl}_{2} 2 \%$ recorded significantly the lowest level of decay. In addition, strawberry-dipped in calcium solution could reduce fruit decay if they were stored under refrigerated conditions at $18{ }^{\circ} \mathrm{C}$ (Garcia et al., 1996). However, no published studies about 'Holland' papaya fruit-treated with chitosan or $\mathrm{CaCl}_{2}$ in case of controlling postharvest decay have been found.

For Shelf-life, the results from Table 7 showed that the application of chitosan or $\mathrm{CaCl}_{2}$ at different concentrations $(0,1.0,1.5,2.0$, and $2.5 \%)$ had a highly significant effect on postharvest life of 'Holland' papaya. Chitosan at $2.5 \%$ had the greatest effect on extending papaya storage life (11.00 days), while fruit-treated with $\mathrm{CaCl}_{2}$, irrespective of any concentration, showed the similar storage duration between 7.50 to 9.33 days. This result is consistent with the findings of Ali (2006) who showed that 0.75 and $1 \%$ chitosan significantly delayed papaya fruit ripening and extended storage life. Similar results were obtained by Gonza'lez-Aguilar et al. (2003) who found that the effectiveness of $2.5 \%$ chitosan treatment prevented water loss, maintained visual appearance, and prolonged postharvest life of papaya. These beneficial effects can be explained by chitosan coatings significantly reduced respiration rate and created modified atmosphere within fruits. These results led to increase the internal $\mathrm{CO}_{2}$ concentrations inside fruit (Sivakumar et al., 2005), reduce fruit respiration metabolism (Bai et al., 1988, El Ghaouth et al., 1991b; Hagenmaier, 2005), decrease weight loss, maintain firmness, delay the color change and fruit ripening and cause extend the storage life (Ali, 2006; da Silva et al., 2007). In addition, Dutta et al. (2009) also cited that chitosan acts as an inhibitor to various enzymes, leading to delay fruit senescence. However, the property of film formed by chitosan, including selective permeability of gas, is related to its molecular characteristic and concentration (Park et al., 2002 and Wiles et al., 2000). There are several results showing that application of chitosan coating effectively extended shelf-life of peeled Litchi fruit (Huaqiang et al., 2004), papaya (Ali, Eryani, \& Raqeeb, 2008), avocado (Salvador, Miranda, Aragon, \& Lara, 1999), fresh-cut Chinese water chestnut (Pen \& Jiang, 2003), tomato (El Ghaouth, et al., 1992a), longan fruit (Jiang \& Li, 2001), fresh-cut strawberries (Campaniello, Bevilacqua, Sinigaglia, \& Corbo, 2008). Nevertheless, the exposure to high concentration of chitosan may increase fruit respiration and induce a stress condition (Devlieghere et al., 2004). This result is not consistent with Joyce, Shorter, and Hockings (2001), who found that delayed ripening of apples (Klein \& Lurie, 1994) and avocados (Wills \& Tirmazi, 1982) was a response to fruit obtained with calcium levels, while Rajkumar et al. (2005) reported that post-harvest dip in $2 \% \mathrm{CaCl}_{2}$ could improve the papaya shelf-life up to nine days. In addition, calcium treatment has been shown to decrease respiration, reduce ethylene production and slow down the onset of ripening in apples (Ferguson, 1984), avocados (Tingwa \& Young, 1974; Rensburg \& Engelbrecht, 1986; Wills \& Sirivatanapa, 1988; Yuen, Caffin, \& Boonyakiat, 1994), mangoes (Tirmazi \& Wills, 1981; Mootoo, 1991; Van Eeden, 1992; Suhardi, 1992), and tomato (Sellars, 2010). However, it should be further investigated to confirm these results with other commercial papaya varieties.

In conclusion, it was found that chitosan coating at $2.5 \%$ exerts beneficial effects on maintaining the maximal fruit firmness, delaying the changes of fruit skin color redness ( $\mathrm{a}^{*}$ value), and the maximal storage life of 11.00 days. However, the application of chitosan, irrespective of any concentrations of $1.0,1.5,2.0$, or $2.5 \%$ had a similar effect to fruit weight loss. In addition, no significant difference in disease appearance was found in papaya treated with chitosan or $\mathrm{CaCl}_{2}$. Thus, chitosan coating at concentration of $2.5 \%$ could be used to maintain the postharvest quality of 'Holland' papaya under ambient temperature by delaying fruit weight loss, advantage affecting the firmness, delayed the color development and extended the shelf-life of papaya fruit. However, 
further study on the mechanism of chitosan against internal characteristic alterations in papaya fruit should be considered.

\section{Acknowledgements}

This research was funded by the Mahasarakham University under project no. 5601028. The authors wish to express their sincere thanks to the Financial Office for financial assistance and Mr. Paul Dulfer for his kindness to improve this manuscript.

\section{References}

Ali, A. (2006). Anthracnose Incidence, Biochemical Changes, Postharvest Quality and Gas Exchange of Chitosan - Coated Papaya (Unpublished PhD's thesis). University of Putra, Malaysia.

Ali, A., Eryani, A., \& Raqeeb, A. (2008). Postharvest quality of papaya fruit (Carica papaya) associated with applications of calcium and chitosan. PhD's thesis, University of Putra, Malaysia. Retrieved from http://psasir.upm.edu.my/4745/

Arriola, M. C., Calzada, J. F., Menchu, J. F., Role, C., \& Garcia, R. (1980). Papaya. In S. Nagy \& P. E. Shaw (Eds.), Tropical and Sub-Tropical Fruits (pp. 316-340). Connecticut, USA: AVI, Westport.

Asgar, A., Muhammad, M. T. M., Sijam, K., \& Siddiqui, Y. (2010). Potential of chitosan coating in delaying the postharvest anthracnose (Colletotrichum gloeosporioides Penz.) of Eksotika II papaya. International Journal of Food Science and Technology, 45(10), 2134-2140. http://dx.doi.org/10.1111/j.1365-2621.2010.02389.x

Bai, R. K., Huang, M. Y., \& Jiang, Y. Y. (1988). Selective permeabilities of chitosan-acetic acid complex membrane for oxygen and carbon dioxide. Polymer Bulletin, 20(1), 83-88. http://dx.doi.org/10.1007/BF00262253

Bautista-Baños, S., Hernández-López, M., Bosquez-Molina, E., \& Wilson, C. L. (2003). Effect of chitosan and plant extract on growth of Colletotrichum gloeosporioides anthracnose level and quality of papaya fruit. Crop Protection, 22(9), 1087-1092. http://dx.doi.org/10.10 16/S0261-2194(03)00117-0

Boonyaritthongchai, P., \& Kanlayanarat, S. (2010). Effect of chitosan and heat treatment on postharvest quality of shredded green papaya. Acta Horticulture, 875, 185-190. Retrieved from http://www.actahort.org/books/875/875_23.htm

Bourne, M. C. (1983). Physical properties and structure of horticultural crops. In M. Peleg \& E. B. Bagley (Eds.), Physical Properties of Foods (pp. 207-228). Westport, CT: AVI Publishing Co.

Butler, B. L., Vregano, P. J., Testin, R. F., Bunn, J. M., \& Wiles, J. L. (1996). Mechanical and barrier properties of edible chitosan films as affected by composition and storage. Journal of Food Science, 61(5), 953-956. http://dx.doi.org/10.1111/j.1365-2621.1996.tb10909.x

Campaniello, D., Bevilacqua, A., Sinigaglia, M., \& Corbo, M. R. (2008). Chitosan: Antimicrobial activity and potential applications for preserving minimally processed strawberries. Food Microbiology, 25(8), 992-1000. http://dx.doi.org/10.1016/j.fm.2008.06.009

Caner, C., Vergano, P., \& Wiles, J. (1998). Chitosan film mechanical and permeation properties as affected by acid, plasticizer, and storage. Journal of Food Science, 63(6), 1049-1053. http://dx.doi.org/10.1111/j.1365-2621.1998.tb15852.x

Caro, Y., \& Joas, J. (2005). Postharvest control of litchi pericarp browning (cv. Kwai Mi) by combined treatments of chitosan and organic acids: II. Effect of the initial water content of pericarp. Postharvest Biology and Technology, 38(2), 137-144. http://dx.doi.org/10. 1016/j.postharvbio.2005.06.012

Chan, H. T., \& Tang, C. S. (1979). The chemistry and biochemistry of papaya. In G. E. Inglett \& G. Charolambous (Eds.), Tropical Foods (Vol. I, pp. 33-53). New York, USA: Academic Press. http://dx.doi.org/10.1021/bi00572a030

Chávez-Sánchez, I., Carrillo-López, A., Vega-García, M., \& Yahia, E. M. (2013). The effect of antifungal hot-water treatments on papaya postharvest quality and activity of pectin methylesterase and polygalacturonase. Journal of Food Technology, 50(1), 101-107. http://dx.doi.org/10.1007/s13197-011-0228-0

Chien, P. J., Sheu, F., \& Yang, F. H. (2007). Effects of edible chitosan coating on quality and shelf-life of sliced mango fruit. Journalof Food Engineering, 78(1), 225-229. http://dx.doi. org/10.1016/j.jfoodeng.2005.09.022 
Conway, W. S., Sams, C. E., Brown, G. A., Beavers, W. B., Tobias, R. B., \& Kennedy, L. S. (1994). Pilot test for the commercial use of postharvest pressure infiltration of calcium into apples to maintain fruit quality in storage. HortTechnology, 4(3), 239-243. $\quad$ Retrieved from http://horttech.ashspublications.org/content/4/3/239.short

Conway, W. S., Sams, C. E., \& Kelman, A. (1994). Enhancing the natural resistance of plant tissues to postharvest diseases through calcium applications. HortScience, 29(7), 751-754. http://dx.doi.org/10.1094/PD-76-0329

Conway, W. S., Sams, C. E., McGuire, R. G., \& Kelman, A. (1992). Calcium treatment of apples and potatoes to reduce postharvest decay. Plant Disease, 76, 329-334. Retrieved from http://www.apsnet.org/publications/PlantDisease/BackIssues/Documents/1992Articles/PlantDisease76n04_ 329.pdf

Coursey, D. G. (1983). Post-harvest losses in perishable foods of the developing world. Post-Harvest Physiology and Crop Preservation, 46, 485-514. http://dx.doi.org/10.1007/978-1-4757-0094-7_23

da Silva, J. A. T., Rashid, Z., Nhut, D. T., Sivakumar, D., Gera, A., Souza Jr., M. T., \& Tennant, P. F. (2007). Papaya (Carica papaya L.) Biology and Biotechnology. Tree and Forestry Science and Biotechnology, 1(1), 47-73. Retrieved from http://www.google.co.th/url?url=http://www.researchgate.net/profile/Dharini_Sivakumar2/ publication/228757793_Papaya(Carica_papaya_L.)_biology_and_biotechnology/links/02e 7e 53628f2b919c b00000033Forigin\%3Dpublication_detail\&rct $=\mathrm{j} \& \mathrm{frm}=1 \& \mathrm{q}=\& \mathrm{esrc}=\mathrm{s} \& \mathrm{sa}=\mathrm{U} \& \mathrm{ei}=\mathrm{jQnvU} 8 \mathrm{v} 8 \mathrm{HY} 7 \mathrm{e} 8 \mathrm{AXAy} 4$ DYDQ\&ved=0CBgQFjAA\&usg=AFQjCNHfgnVLfOhxcdBjc6wzddVIei Wj0g

Darmadji, P., \& Izumimoto, M. (1994). Effect of chitosan in meat preservation. Meat Science, 38(2), 243-254. http://dx.doi.org/10.1016/0309-1740(94)90114-7

De La Cruz Medina, J., Gutiérrez, G. V., \& García, H. S. (2003). PAWPAW: Post-harvest Operation. In D. Mejía (Ed.), Organisation: Instituto Tecnológico de Veracruz (ITV) (p. 70). AGSI/FAO: AGST, FAO (Technical).

Devlieghere, F., Vermeulen, A., \& Debevere, J. (2004). Chitosan: Antimicrobial activity, interactions with food components and applicability as a coating on fruit and vegetables. Food Microbiology, 21(6), 703-714. http://dx.doi.org/10.1016/j.fm.2004.02.008

Dong, H., Cheng, L., Tan, J., Zheng, K., \& Jiang, Y. (2004). Effects of chitosan coating on quality and shelf-life of peeled litchi fruit. Journal of Food Engineering, 64(3), 355-358. http://dx.doi.org/10.1016/j.jfoodeng.2003.11.003

Ducamp-Collin, M. N., Ramarson, H., Lebrun, M., Self, G., \& Reynes, M. (2008). Effect of citric acid and chitosan on maintaining red colouration of litchi fruit pericarp. Postharvest Biology and Technology, 49(2), 241-246. http://dx.doi.org/10.1016/j.postharvbio 200801.009

Dutta, P. K., Tripathi, S., Mehrotra, G. K., \& Dutta, J. (2009). Perspectives for chitosan based antimicrobial films in food applications. Food Chemistry, 114(4), 1173-1182. http://dx. doi.org/10.1016/j.foodchem.2008.11.047

El-Ghaouth, A., Arul, J., Ponnampalam, R., \& Boulet, M. (1991a). Chitosan coating effect on storability and quality of fresh strawberries. Journal of Food Science, 56(6), 1618-1620. http://dx.doi.org/10.1111/j.1365-2621.1991.tb08655.x

El Ghaouth, A., Arul, J., \& Asselin, A. (1991b). Potential use of chitosan in postharvest preservation of fruits and vegetables. In C. J. Brines, P. A. Sandfors, \& J. P. Zikakis (Eds.), Advances in Chitin and Chitosan (pp. 440-452). London, England: Elsevier Science Publishers.

El Ghaouth, A., Arul, J., \& Ponnampalam, R. (1991c). Use of chitosan coating to reduce weight loss and maintain quality of cucumbers and bell pepper fruits. Journal of Food Processing and Preservation, 15(5), 359-368. http://dx.doi.org/10.1111/j.1745-4549.1991.tb00178.x

El-Ghaouth, A., Ponnampalam, R., Castaigne, F., \& Arul, J. (1992a). Chitosan coating to extend the storage life of tomatoes. HortScience, 27(9), 1016-1018. Retrieved from http://fst.sage pub.com/content/18/2/123.full

EI Ghaouth, A., Arul, J., Grenier, J., \& Asselin, A. (1992b). Antifungal activity of chitosan on two post-harvest pathogens of strawberry fruits. Phytopathology, 82, 398-402. http://dx. doi.org/10.1094/Phyto-82-398

El-Ghaouth, A., Smilanick, J. L., \& Wilson, C. L. (2000). Enhancement of the performance of Candida saitoana by the addition of glycolchitosan for the control of postharvest decay of apple and citrus fruit. Postharvest Biology and Technology, 19(1), 103-110. http://dx. doi.org/10.1016/S0925-5214(00)00076-4

Eryani-Raqeeb, A. A., Mahmud, T. M. M., \& Omar, S. R. S. (2009). Effects of calcium and chitosan treatments on controlling anthracnose and postharvest quality of papaya (Carica papaya L.). International Journal 
Agricultural Research, 4(2), 53-68. http://dx.doi.org/ 10.3923/ijar.2009.53.68

Ferguson, I. B. (1984). Calcium in plant senescence and fruit ripening. Plant Cell Environment, 7(6), 477-489. http://dx.doi.org/10.1111/j.1365-3040.1984.tb01438.x

Garcia, J. M., Herrera, S., \& Morilla, A. (1996). Effects of postharvest dips in calcium chloride on strawberry. Journal of Agricultural and Food Chemistry, 44(1), 30-33. http://dx.doi.org/10.1021/jf9503341

Gonza'lez-Aguilar, G. A., Buta, J. G., \& Wang, C. Y. (2003). Methyl jasmonate and modified atmosphere packaging (MAP) reduce decay and maintain postharvest quality of papaya 'Sunrise'. Postharvest Biology and Technology, 28(3), 361-370. http://dx.doi.org/10.10 16/S0925-5214(02)00200-4

Goupy, P., Amiot, M. J., Richard-Forget, F., Duprat, F., Aubert, S., \& Nicolas, J. (1995). Enzyma tic browning of model soutions and apple phenolic substrates by apple polyphenoloxi dase. Journal of Food Science, 60(3), 497-501. http://dx.doi.org/10.1111/j.1365-2621.1995.tb09811.x

Hagenmaier, R. D. (2005). A comparison of ethane, ethylene and $\mathrm{CO}_{2}$ peel permeance for fruit with different $\begin{array}{lllll}\text { coatings. Postharvest Biology and Technology, 37(1), } & \text { 56-64. }\end{array}$ http://dx.doi.org/10.1016/j.postharvbio.2005.02.012

Han, C., Zhao, Y., Leonard, S. W., \& Traber, M. G. (2004). Edible coatings to improve storability and enhance nutritional value of fresh and frozen strawberries (Fragaria $\times$ ananassa) and raspberries (Rubus ideaus). Postharvest Biology and Technology, 33(1), 67-78. http://dx. doi.org/10.1016/j.postharvbio.2004.01.008

Hayes, W. B. (1993). Fruit Growing in India. Allahabad, India: Kitabistan.

Hernández-Muñoz, P., Almenar, E., Ocio, M. J., \& Gavara, R. (2006). Effect of calcium dips and chitosan coatings on postharvest life of strawberries (Fragaria x ananassa). Postharvest Biology and Technology, 39(3), 247-253. http://dx.doi.org/10.1016/j.postharvbio.2005. 11.006

Huang, X. M., Wang, H. C., Zhong, W. L., Yuan, W. Q., Lu, J. M., \& Li, J. G. (2008). Spraying calcium is not an effective way to increase structural calcium in litchi pericarp. Scientia Horticulture, 117(1), 39-44. http://dx.doi.org/10.1016/j.scienta.2008.03.007

Huaqiang, D., Cheng, L., Tan, J., Zheng, K., \& Jiang, Y. (2004). Effects of chitosan coating on quality and shelf-life of peeled litchi fruit. Journal of Food Engineering, 64(3), 355-358. http://dx.doi.org/10.1016/j.jfoodeng.2003.11.003

Hundtoft, E. B., \& Akamine, E. K. (1971). Establishing the effects of postharvest treatment on fresh market papayas by response surface methodology. Journal of Agricultural Engineering Research, 16(4), 343-352. http://dx.doi.org/10.1016/S0021-8634(71)80033-1

Izumi, H., \& Watada, A. E. (1995). Calcium treatment to maintain quality of zucchini squash slices. Journal of Food Science, 60(4), 789-793. http://dx.doi.org/10.1111/j.1365-2621.1995.tb06230.x

Jayakumar, R., Nwe, N. T., Tokura, S., \& Tamura, H. (2007). Sulfated chitin and chitosan as novel biomaterials. International Journal of Biological Macromolecules, 40(3), 175-181. http://dx.doi.org/10.1016/j.ijbiomac.2006.06.021

Jayakumar, R., Prabaharan, M., Reis, R. L., \& Mano, J. F. (2005). Graft copolymerized chitosan - present status and applications. Carbohydrate Polymers, 62(2), 142-158. http://dx.doi. org/10.1016/j.carbpol.2005.07.017

Jayakumar, R., Reis, R. L., \& Mano, J. F. (2006). Chemistry and Applications of Phosphorylated Chitin and Chitosan. e-Polymers, 35, 1-16. Retrieved from http://www.e-polymers.org

Jayathunge, K. G. L. R., Prasad, H. U. K. C., Fernando, M. D., \& Palipane, K. B. (2011). Prolonging the postharvest life of papaya using modified atmosphere packaging. Journal of Agricultural Technology, 7(2), 507-518. Retrieved from http://www.ijat-aatsea.com

Jha, S. K., Sethi, S., Srivastav, M., Dubey, A. K., Sharma, R. R., Samuel, D. V. K., \& Singh, A. K. (2010). Firmness characteristics of mango hybrids under ambient storage. Journal of Food Engineering, 97(2), 208-212. http://dx.doi.org/10.1016/j.jfoodeng.2009.10.011

Jiang, Y., \& Li, Y. (2001). Effects of chitosan coating on postharvest life and quality of longan fruit. Food Chemistry, 73(2), 139-143. http://dx.doi.org/10.1016/S0308-8146(00)00246-6

Jongrittiporn, S., Kungsuwan, A., \& Rakshit, S. K. (2001). A study on the preservation of fishballs using chitosan. Paper presented at the European Conference on Advanced Technology for Safe and High Quality Foods-EUROCAFT. Berlin. 
Joyce, D. C., Shorter, A. J., \& Hockings, P. D. (2001). Mango fruit calcium levels and the effect of postharvest calcium infiltration at different maturities. Scientia Horticulturae, 91(1-2), 81-99. http://dx.doi.org/10.1016/S0304-4238(01)00247-3

Kakaew, P., Nimitkeatkai, H., Srilaong, V., \& Kanlayanarat, S. (2007). Effects of $\mathrm{CaCl}_{2}$ dips and heat treatments on quality and shelf-life of shredded green papaya. Acta Horticulturae, 746, 335-342. Retrieved from http://www.actahort.org/books/746/746_39.htm

Klein, J. D., \& Lurie, S. (1992). Heat Treatments for Improved Postharvest Quality of Horticultural Crops. HortTechnology, 2(3), 316-320. Retrieved from http://horttech.ashspublications.org/content/2/3/316.short

Klein, J. D., \& Lurie, S. (1994). Time, temperature, and calcium interact in scald reduction and firmness retention in heated apples. HortScience, 29(3), 194-195. Retrieved from http://hortsci.ashspublications.org/content/29/3/194.abstract

Krongyut, W., Srilaong, V., Uthairatanakij, A., Wongs-Aree, C., Esguerra, E. B., \& Kanlayanarat, S. (2011). Physiological changes and cell wall degradation in papaya fruits cv. 'Kaek Dum' and 'Red Maradol' treated with 1-methylcyclopropene. International Food Research Journal, 18(4), 1251-1259. Retrieved from $\mathrm{http} / /$ connection.ebscohost.com/c/articles/64500192/physiological-changes-cell-wall-degradation-papaya-f ruits-cv-kaek-dum-red-maradol-treated-1-methylcyclopropene

Lester, G. E., \& Grusak, M. A. (1999). Postharvest application of calcium and magnesium to honeydew and netted muskmelons: Effects on tissue ion concentrations, quality, and senescence. Journal American Society for Horticultural Science, $\quad$ 124(5), 545-552. Retrieved from http://journal.ashspublications.org/content/124/5/545.abstract

Li, H., \& Yu, T. (2001). Effect of chitosan on incidence of brown rot, quality and physiological attributes of postharvest peach fruit. Journal of the Science of Food and Agriculture, 81(2), 269-274. http://dx.doi.org/10.1002/1097-0010(20010115)

Li, Q., Dunn, E. T., Grandmaison, E. W., \& Goosen, M. F. A. (1992). Applications and properties of chitosan. Journal of Bioactive and Compatible Polymers, $370-397$. http://dx.doi.org/10.1177/088391159200700406

Luna-Guzmán, I., Cantwell, M., \& Barrett, D. M. (1999). Fresh-cut cantaloupe: Effects of $\mathrm{CaCl}_{2}$ dips and heat treatments on firmness and metabolic activity. Postharvest Biology and Technology, 17(3), 201-213. http://dx.doi.org/10.1016/S0925-5214(99)00048-4

Maftoonazad, N., \& Ramaswamy, H. S. (2005). Postharvest shelf-life extension of avocados using methyl cellulose-based coating. LWT - Food Science and Technology, 38(6), 617-624. http://dx.doi.org/10.1016/j.lwt.2004.08.007

Mahajan, B. V. C., \& Dhatt, A. S. (2004). Studies on postharvest calcium chloride application on storage behaviour and quality of Asian pear during cold storage. International Journal of Food Agriculture and Environment, 2(3-4), 157-159. Retrieved from http://world-food.net/studies-on-postharvest-calcium-chloride-applicationon-storage-behaviour-and-quality-of-asian-pear-during-cold-storage/

Manganaris, G. A., Vasilakakis, M., Diamantidis, G., \& Mignani, I. (2007). The effect of postharvest calcium application on tissue calcium concentration, quality attributes, incidence of flesh browning and cell wall physicochemical aspects of peach fruits. Food Chemistry, 100(4), 1385-1392. http://dx.doi.org/10.1016/j.foodchem.2005.11.036

Maria, A. R. G., Tapiab, M. S., \& Bellosoa, O. M. (2008). Using polysaccharide-based edible coatings to maintain quality of fresh-cut Fuji apples. LWT-Food Science and Technology, 41(1), 139-147. http://dx.doi.org/0.1016/j.lwt.2007.01.009

Martínez-Castellanos, G., Shirai, K., Pelayo-Zaldívar, C., Pérez-Flores, L. J., \& Sepúlveda-Sán chez, J. D. (2009). Effect of Lactobacillus plantarum and chitosan in the reduction of browning of pericarp Rambutan (Nephelium lappaceum). Food Microbiology, 26(4), 444-449. http://dx.doi.org/10.1016/j.fm.2009.02.003

Mastrocola, D., \& Lerici, C. R. (1991). Colorimetric measurements of enzymatic and non-enzymatic browning in apple purees. International Journal of Food Science, 3(4), 219-229. Retrieved from http://europepmc.org/abstract/AGR/IND92056818

McDonald, R. E., McCollum, T. G., \& Baldwin, E. A. (1998). Heat treatment of mature-green tomatoes: Differential effects of ethylene and partial ripening. Journal American Society for Horticultural Science, 
123(3), 457-462. Retrieved from http://journal.ashspublica tions.org/content/123/3/457.abstract

McGuire, R. G. (1992). Reporting of objective color measurements. HortScience, 27(12), 1254-1255. Retrieved from http://hortsci.ashspublications.org/content/27/12/1254.full.pdf\%2 Bhtml

Monsalve-González, A., Barbosa-Cánovas, G. V., Cavalieri, R. P., McEvily, A. J., \& Iyengar, R. (1993). Control of browning during storage of apple slices preserved by combined methods, 4-hexylresorcinol as antibrowning agent. Journal of Food Science, 58(4), 797-800. http://dx.doi.org/10.1111/j.1365-2621.1993.tb09361.x

Mootoo, A. (1991). Effect of postharvest calcium chloride dips on ripening changes in 'Julie' mangoes. Tropical Science, 31(3), 243-248. Retrieved from http://openagricola.nal. usda.gov/Record/IND91043456

No, H. K., \& Meyers, S. P. (1997). Preparation of chitin and chitosan. In R. A. A. Muzzarelli \& M.G. Peter (Eds.), Chitin Handbook (pp. 475-489). Grottammare AP, Italy: European Chitin Society.

Olivas, G. I., \& Barbosa-Cánovas, G. V. (2005). Edible coatings for fresh-cut fruits. Critical Reviews in Food Science and Nutrition, 45(7-8), 657-670. http://dx.doi.org/10.1080/10408690490911837

Park, S. Y., Marsh, K. S., \& Rhim, J. W. (2002). Characteristics of different molecular weight chitosan films affected by the type of organic solvents. Journal of Food Science, 67(1), 194-197. http://dx.doi.org/10.1111/j.1365-2621.2002.tb11382.x

Paull, R. E., \& Chen, N. J. (1983). Postharvest Variation in Cell Wall-Degrading Enzymes of Papaya (Carica papaya L.) during Fruit Ripening. Plant Physiology, 72(2), 382-385. http://dx.doi.org/10.1104/pp.72.2.382

Paull, R. E., \& Chen, N. J. (1989). Waxing and plastic wraps influence water loss from papaya fruit during storage and ripening. Journal American Society for Horticultural Science, 114(6), 937-942.

Pen, L. T., \& Jiang, Y. M. (2003). Effects of chitosan coating on shelf-life and quality of fresh-cut Chinese water chestnut. Lebensmittel-Wissenschaft und-Technologie, 36(3), 359-364. $\mathrm{http}: / / \mathrm{dx}$.doi.org/10.1016/S0023-6438(03)00024-0

Picchioni, G. A., Watada, A. E., Conway, W. S., Whitaker, B. D., \& Sams, C. E. (1995). Phospho lipid, galactolipid, and steryl lipid composition of apple fruit cortical tissue following postharvest $\mathrm{CaCl}_{2}$ infiltration. Phytochemistry, 39(4), 763-769. http://dx.doi.org/10.10 16/0031-9422(95)00068-I

Pen, L. T., \& Jiang, Y. M. (2003). Effects of chitosan on shelf-life and quality of fresh-cut Chinese water chestnut. Lebensmitte Wissenschaft $\quad$ und 359-364. http://dx.doi.org/10.1016/S0023-6438(03)00024-0

Phummalee, S. (2013). Holland Papaya. Center for career development and promotion of agricultural Nakhon Ratchasima (Horticulture), 5(56), 1-2. Retrieved from http://papaya-trip.blogspot.com/

Poovaiah, B. W. (1986). Role of calcium in prolonging storage life of fruits and vegetables. Food Technology, 40, 86-89. Retrieved from http://agris.fao.org/agris-search/search.do?recordID=US8712640

Postharvest Handling Technical Bulletin. (2003). PAPAYA Postharvest Care and Market Preparation. Technical Bulletin, 5, 1-13. Retrieved from http://www.google.co.th/url?url=http://pdf.usaid.gov/pdf docs/Pnacy821. pdf\&rct=j\&frm=1\&q=\&esrc=s\&sa=U\&ei=y2TxU7_YKZCPuASF4YKQDA\&ved=0CBcQFjAA\&usg=AF QjCNGozR0AiR1-gBBCEudDWqjgAMglxw

Proulx, E., Cecilia, M., Nunes, M. C. N., Emond, J. P., \& Brecht, J. K. (2005) Quality attributes limiting papaya post harvest life at chilling and non-chilling temperatures. Proceedings of the Florida State Horticultural Society, 118, 389-395. Retrieved from http://www.google.co.th/url?url=http://hos.ufl.edu/sites/default/files /faculty/jkbrecht/publications/Proulx\%2520et\%2520al\%25202005\%2520118,\%2520389-395.pdf\&rct=j\&fr $\mathrm{m}=1 \& \mathrm{q}=\&$ esrc $=\mathrm{s} \& \mathrm{sa}=\mathrm{U} \& \mathrm{ei}=\mathrm{VmfxU} 6 \mathrm{fwNNCRuATz04KoDA \& ved=0 \textrm {CBgQFjAA } \& u s g = A F Q j C N F c j M v g}$ 4kMEa95Ja-jcSquZ4A7lzA

Qiuping, Z., \& Wenshui, X. (2007). Effect of 1-methylcyclopropene and/or chitosan coating treatments on storage life and quality maintenance of Indian jujube fruit. LWT - Food Science and Technology, 40(3), 404-411. http://dx.doi.org/10.1016/j.lwt.2006.01.003

Rajkumar, M., Karuppaiah, P., \& Kandasamy, R. (2005). Effect of calcium and gibberellic acid on post-harvest behaviour of papaya cv. Co2. Indian Journal of Horticulture, 62(4), 327-331. Retrieved from http://www.indianjournals.com/ijor.aspx?target $=$ ijor:ijh\&volume $=62 \&$ issue $=4 \&$ article $=004$

Reddy, M. V. B., Belkacemi, K., Corcuff, R., Castaigne, F., \& Arul, J. (2000). Effect of pre-harvest chitosan sprays on post-harvest infection by Botrytis cinerea and quality of strawberry fruit. Postharvest Biology and 
Technology, 20(1), 39-51. http://dx.doi.org/ 10.1016/S0925-5214(00)00108-3

Rensburg, E. V., \& Engelbrecht, A. H. P. (1986). Effect of calcium salts on susceptibility to browning of avocado fruit. Journal of Food Science, 51(4), 1067-1068. http://dx.doi.org/10.1111/j.1365-2621.1986.tb11235.x

Romanazzi, G., Nigro, F., Ippolito, A., Di Venere, D., \& Salerno, M. (2002). Effects of pre- and postharvest chitosan treatments to control storage grey mold of table grapes. Journal of Food Science, 67(5), 1862-1867. http://dx.doi.org/10.1111/j.1365-2621.2002.tb08737.x

Rosen, J. C., \& Kader, A. A. (1989). Postharvest physiology and quality maintenance of sliced pear and strawberry fruits. Journal of Food Science, 54(3), 656-659. http://dx.doi.org/10.1111/j.1365-2621.1989.tb04675.x

Saftner, R. A., Conway, W. S., \& Sams, C. E. (1998). Effects of postharvest calcium and fruit coating treatments on postharvest life, quality maintenance, and fruit-surface injury in 'Golden Delicious' apples. Journal American Society for Horticultural Science, 123(2), 294-298. Retrieved from http://journal.ashspublications.org/content/123/2/294.abstract

Salunkhe, D. K., Boun, H. R., \& Reddy, N. R. (1991). Storage processing and nutritional quality of fruits and vegetables. Boston, USA: CRC Press Inc.

Salvador, L., Miranda, S. P., Aragon, N., \& Lara, V. (1999). Chitosan coating on avocado fruit. Revista de la Sociedad Quimica de Mexico., 43(1), 18-23. Retrieved from http://www.google.co.th/url?url=http://www.jmcs.org.mx/PDFS/V43/SMQ-V043\%2520N-001_ligas_size.p $\mathrm{df} \& \mathrm{rct}=\mathrm{j} \& \mathrm{frm}=1 \& \mathrm{q}=\& \mathrm{esrc}=\mathrm{s} \& \mathrm{sa}=\mathrm{U} \& \mathrm{ei}=\mathrm{HX} 3 \mathrm{xU}$ 7OZA82yuATGzICADg\&ved=0CCEQFjAD\&usg=AFQj CNHcEqtaVuJ6Z8MwWPu25RmcsABpnQ

Sellars, B. (2010). Calcium Chloride Uses on Tomatoes. Retrieved from http://www.ehow.com/list_6082729_calcium-chloride-uses-tomatoes.html

Shahidi, F., Kamil, J., Arachchi, V., \& Jeon, Y. J. (1999). Food applications of chitin and chitosans. Trends in Food Science \& Technology, 10(2), 37-51. http://dx.doi.org/10.1016/S0924-2244(99)00017-5

Sharma, N., \& Alam, M. M. (1998). Postharvest Diseases of Horticultural Perishables. Lucknow, India: International Book Distributing Company.

Singh, I. D. (1990). Papaya. New Delhi, India: Oxford and IBH Publishing Company Private Limited.

Sivakumar, D., Sultanbawa, Y., Ranasingh, N., \& Wijesundera, R. L. C. (2005). Effect of the combined application of chitosan and carbonate salts on the incidence of anthracnose and on the quality of papaya during storage. The Journal of Horticultural Science and Biotechnology, 80(4), 447-452. Retrieved from http://espace.library.uq.edu.au/view/UQ: 250737

Somsri, S. (2014). Current status of papaya production in Thailand. Acta Horticulturae, 1022, 31-45. Retrieved from http://www.actahort.org/books/1022/1022_3.htm

SPSS. (1999). Base 9.0 for Windows Users Guide. USA.: SPSS Inc.

Suhardi, Y. (1992). Ripening retardation of Arumanis mango. ASEAN Food Journal, 7(4), 207-208. Retrieved from http://www.phtnet.org/research/view-abstract.asp?research_id=wi 282

Tasiwal, V. (2008). Studies on Anthracnose-A postharvest disease of papaya. (Doctoral dissertation). Retrieved from http://www.google.co.th/url?url=http://etd.uasd.edu/abst/th9784.pdf\&rct=j\&frm=1\&q=\&esrc=s\&sa=U \&ei=YZHxU_TbPIWGuATI1ICYDA\&ved=0CBUQFjAB\&usg=AFQjCNESmmoMKbd2-kqVU96xATx72 Q_SNQ

Tingwa, P. O., \& Young, R. E. (1974). The effect of calcium on the ripening of avocado (Persea americana Mill.) fruits. Journal American Society for Horticultural Science, 99(6), 540-542. Retrieved from http://www.researchgate.net/publication/255667210_The_Effect_of_Calcium_on_the_Ripening_of_Avocad o_(Persea_americana_Mill.)_Fruits1

Tirmazi, S. I. H., \& Wills, R. B. H. (1981). Retardation of ripening of mangoes by postharvest application of calcium. Tropical Agriculture, 58, 137-141.

Van Eeden, S. J. (1992). Calcium infiltration as a possible postharvest treatment to increase storage potential of mango fruit. South African Mango Growers' Association Yearbook, 12, 26-27. Retrieved from http://www.phtnet.org/research/view-abstract.asp?research_id=wi136

Vargas, M., Albors, A., Chiralt, A., \& González-Martínez, C. (2006). Quality of cold-stored strawberries as affected by chitosan-oleic acid edible coatings. Postharvest Biology and Technology, 41(2), 164-171. 
http://dx.doi.org/10.1016/j.postharvbio.2006.03.016

Verheij, E. (1991). Edible Fruits and Nuts: No 2 (PROSEA - plant resources of South East Asia). Netherlands: Backhuys Publishers.

Wang, G. (1992). Inhibition and Inactivation of Five Species of Foodborne Pathogens by Chitosan. Journal of Food Protection, 55(11), 916-919. Retrieved from http://cat.inist.fr/?aModele=afficheN\&cpsidt=4602388

Wiles, J. L., Vergano, P. J., Barron, F. H., Bunn, J. M., \& Testin, R. F. (2000). Water vapor transmission rates and sorption behavior of chitosan films, Journal of Food Science, 65(7), 1175-1179. http://dx.doi.org/10.1111/j.1365-2621.2000.tb10261.x

Wills, R. B. H., \& Sirivatanapa, S. (1988). Evaluation of postharvest infiltration of calcium to delay the ripening of avocados. Australian Journal of Experimental Agriculture, 28(8), 801-804. http://dx.doi.org/10.1071/EA9880801

Wills, R. B. H., \& Tirmazi, S. I. H. (1982). Inhibition of ripening of avocados with calcium. Scientia Horticulturae, 16(4), 323-330. http://dx.doi.org/10.1016/0304-4238(82)90031-0

Wong, D. W. S., Gastineau, F. A., Gregorski, K. A., Tillin, S. J., \& Pavlath, A. E. (1992). Chitosan-Lipid Films: Microstructure and Surface Energy. Journal of Agricultural and Food Chemistry, 40(4), 540-544. http://dx.doi.org/10.1021/jf00016a002

Xianghong, M., Li, B., Liu, J., \& Tian, S. (2008). Physiological responses and quality attributes of table grape fruit to chitosan preharvest spray and postharvest coating during storage. Food Chemistry, 106(2), 501-508. http://dx.doi.org/10.1016/j.foodchem.2007.06.012

Yuen, C. M. C., Caffin, N., \& Boonyakiat, D. (1994). Effect of calcium infiltration on ripening of avocados at different maturities. Australian Journal of Experimental Agriculture, 34, 123-126. http://dx.doi.org/10.1071/EA9940123

Zhang, D. L., \& Quantick, P. C. (1997). Effects of Chitosan Coating on Enzymatic Browning and Decay During Postharvest Storage of Litchi Fruit. Postharvest Biology and Technology, 12(2), 195-202. http://dx.doi.org/10.1016/S0925-5214(97)00057-4

Zhang, D. L., \& Quantick, P. C. (1998). Antifungal effects of chitosan coating on fresh strawberries and raspberries during storage. Journal of Horticultural Science and Biotechnology, 73(6), 763-767. Retrieved from http://www.jhortscib.org/members/show document?session=26468

\section{Copyrights}

Copyright for this article is retained by the author(s), with first publication rights granted to the journal.

This is an open-access article distributed under the terms and conditions of the Creative Commons Attribution license (http://creativecommons.org/licenses/by/3.0/). 